\title{
Ocena efektywności procesu dyplomowania na studiach pierwszego stopnia w polskich publicznych uczelniach technicznych
}

\begin{abstract}
STRESZCZENIE: W artykule przedstawiono analizę i ilościową ocenę funkcjonowania 18 polskich uczelni technicznych uwzględniającą dwa podstawowe problemy: rezygnację ze studiów w trakcie pierwszego roku oraz wskaźniki ukończenia studiów w nominalnym czasie. Do oceny efektywności procesu dyplomowania wykorzystano prostą metodę wskaźnikową oraz nieparametryczną metodę Data Envelopment Analysis (DEA). Ocenę przeprowadzono dla studiów pierwszego stopnia prowadzonych w formie stacjonarnej i niestacjonarnej. Na podstawie prostych wskaźników dokonano wstępnej oceny zjawiska. W modelu DEA uwzględniono po stronie nakładów liczbę studentów rozpoczynających studia w 2011 roku, liczbę nauczycieli akademickich oraz całkowitą liczbę studentów pierwszego stopnia. Po stronie rezultatów uwzględniono liczbę absolwentów z roku 2015 oraz liczbę osób, które zrezygnowały po pierwszym roku studiów. Model ten pozwolił na stworzenie rankingu oraz obliczenie pożądanych wartości zmiennych uwzględnionych w analizie, dla uczelni nieefektywnych. W interpretacji wyników uwzględniono wcześniej zdefiniowane wskaźniki.
\end{abstract}

SŁOWA KLUCZOWE: wskaźnik ukończenia studiów, wskaźnik rezygnacji w pierwszym roku studiów, analiza wskaźnikowa, data envelopment analysis, niepożądane rezultaty

\section{Wstęp}

Dynamiczny wzrost zainteresowania studiami wyższymi na świecie potwierdzają dane statystyczne. W latach 1970-2016 współczynnik skolaryzacji brutto zwiększył się w skali światowej z 10.06\% do 36.77\%; w krajach OECD z 23.50\% do 72.78\%; a w krajach UE z 17.32\% do 67.67\% (World Bank 2018). Masowość kształcenia na poziomie wyższym ma niewątpliwie negatywny wpływ na jego jakość, na co już w latach 70. poprzedniego stulecia zwrócił uwagę Trow (1973). Carneiro, Heckman i Vytlacil (2011) stwierdzili natomiast, że polityka rozszerzająca możliwości edukacji wyższej w wielu krajach skłania do podejmowania studiów przez wielu młodych ludzi, którzy ze względu na swoje możliwości nie powinni w nich uczestniczyć. Stąd 
w analizach funkcjonowania systemów edukacji wyższej coraz większą uwagę zwraca się na zjawisko porzucania studiów w pierwszym roku (first year dropout) i stopy ukończenia studiów (graduation rates) (Sneyers i De Witte 2017; Barra i Zotti 2016; Thomas i Hovdhaugen 2014).

W dobie masowego kształcenia ważne jest, aby w analizach systemów edukacyjnych poza spojrzeniem z perspektywy ilościowej uwzględniać również aspekty jakościowe. Podkreśla się jednak, że pomiar jakości jest znacznie trudniejszy niż uzyskanie miar ilościowych. Johnes i Tone (2017) stwierdzają, że podejście ilościowe jest ważne, ale uwzględnienie jakości procesu kształcenia jest jeszcze bardziej istotne. Pomimo trudności ze sformułowaniem odpowiednich mierników ocenianie jakości funkcjonowania procesów nauczania uniwersyteckiego jest bezwzględnie konieczne w kontekście polityki edukacyjnej (Agasisti i Johnes 2015).

Liczba osób z wykształceniem wyższym ogólnie rośnie w European Higher Education Area (Europejskim Obszarze Szkolnictwa Wyższego - EHEA), a tendencja ta jest wyraźnie pozytywnie oceniana ze względu na szybko rosnące wymagania stawiane przez gospodarkę opartą na wiedzy. Stwierdza się również, że podobnie jak na całym świecie zbyt wielu europejskich studentów przedwcześnie rezygnuje z edukacji. Jednakże dostępność danych na ten temat i ich porównywalność wciąż stanowi poważny problem. Na podstawie dostępnych danych wskaźniki ukończenia studiów wahają się w krajach Unii Europejskiej w przedziale od 48\% do 88\% (EACEA-Eurydice 2015).

Zdaniem Vossensteyn i in. (2015) brakuje w Europie systematycznej wiedzy, danych i wskaźników na temat sukcesu studiowania. Chociaż istnieje wiele badań dotyczących czynników, które mogą mieć wpływ na sukces studiowania poszczególnych studentów, badania nad polityką sukcesu studiowania i jej skutecznością należą do rzadkości. Ponadto dane dostępne w krajach europejskich są zróżnicowane pod względem dostępności, metody zbierania danych, definicji i zastosowań. Takie mierniki jak wskaźniki ukończenia studiów, wskaźniki retencji czy rezygnacji ze studiów i średniego czasu potrzebnego do uzyskania dyplomu są trudno dostępne. Tylko 12 spośród 35 krajów europejskich regularnie raportuje krajowy wskaźnik ukończenia studiów. Jeszcze mniej krajów raportuje wskaźniki retencji, wskaźniki rezygnacji ze studiów i czas potrzebny do uzyskania dyplomu. Podobne problemy obserwuje się również w innych krajach, np. Australii i Stanach Zjednoczonych (Vossensteyn i in. 2015).

Można sformułować pytanie, w jaki sposób prowadzić badania porównawcze, uwzględniając takie czynniki jak rezygnacja ze studiów i terminowe ich ukończenie przez studentów? Międzynarodowe badania porównawcze są wyzwaniem i obserwuje się potrzebę kontynuowania dyskusji na temat metodyki, która powinna uwzględniać kontekst lokalny. Oznacza to, że ogólne wnioski można wyciągnąć z różnych 
krajowych systemów szkolnictwa wyższego i przenieść je na grunt porównań międzynarodowych (Thomas i Hovdhaugen 2014).

Celem tego artykułu jest analiza i ilościowa ocena funkcjonowania polskich uczelni technicznych w kontekście wcześniej przedstawionych problemów rezygnacji ze studiów w trakcie pierwszego roku wraz ze wskaźnikami ich ukończenia. Do oceny efektywności procesu dyplomowania wykorzystano prostą metodę wskaźnikową oraz nieparametryczną metodę Data Envelopment Analysis (DEA).

Artykuł składa się z czterech części, wstępu i zakończenia. Pierwsza z nich zawiera analizę literatury w kontekście jakości funkcjonowania szkolnictwa wyższego. Druga część to opis metodyki zastosowanej w badaniach. W kolejnej znajduje się opis danych oraz dobór zmiennych do modelu. Ostatnia część zawiera analizę i dyskusję wyników przeprowadzonych badań. Artykuł kończy się krótkim podsumowaniem.

\section{Problematyka pomiaru jakości funkcjonowania szkolnictwa wyższego w literaturze}

Jest pełna zgodność, że instytucje szkolnictwa wyższego to złożone, wieloproduktowe organizacje. Ich podstawowe obszary aktywności to badania naukowe, nauczanie i tzw. trzecia misja (np. Kallio, Kallio i Grossi 2017; Agasisti i Johnes 2015; Daraio, Bonaccorsi i Simar 2015b; Safón 2013; Bonaccorsi i Daraio 2008; Murias, de Miguel i Rodriguez 2008; Bonaccorsi, Daraio i Simar 2006; Abbott i Doucouliagos 2003). Trzecią misję można scharakteryzować jako angażowanie się uczelni w transfer wyników badań naukowych do przemysłu oraz aktywne przyczynianie się do wzrostu gospodarczego na poziomie krajowym i lokalnym (Bonaccorsi, Daraio i Simar 2006) czy też szeroko rozumiane usługi dla społeczeństwa (Abbott i Doucouliagos 2003). Ze względu na trudności w określeniu właściwych mierników dotyczących trzeciej misji oraz braku odpowiednich danych ten obszar aktywności uniwersytetów zwykle nie jest uwzględniany w analizach (Agasisti i Johnes 2015; Daraio, Bonaccorsi i Simar 2015b). Ponieważ uczelnie produkują łącznie badania i nauczanie w różnych dziedzinach i na różnych poziomach, utrudnia to ocenę ich funkcjonowania. Często instytucja działająca dobrze w jednym wymiarze może być gorsza w innym (Agasisti i Johnes 2015). Niektóre uczelnie mają wyraźne ukierunkowanie badawcze, a inne specjalizują się w nauczaniu (De Witte i Hudrlikova 2013).

Pomimo tego, że uniwersytety są postrzegane jako wieloproduktowe organizacje, dla celów osiągniecia większej wiarygodności wyników dokonuje się często oddzielenia analizy funkcjonowania w zakresie kształcenia i badań, bazując na założeniu, że oba typy działalności są realizowane niezależnie (Sarrico i in. 2009; Johnes 1996). Zdaniem Johnes (1996) odrębne mechanizmy finansowania stosowane w nauczaniu i badaniach w sektorze szkolnictwa wyższego wspierają takie założenie. 


\subsection{Nakłady i rezultaty w analizie efektywności nauczania}

W badaniach efektywności instytucji szkolnictwa wyższego specyfikacja nakładów i rezultatów ich działania jest niezwykle trudna, ponieważ są one zróżnicowane i często niemożliwe do bezpośredniego pomiaru. Stąd najczęściej stosowane są proxy dla większości nakładów i rezultatów funkcjonowania uczelni (Carrington, Coelli i Prasada Rao 2005).

W zależności od celu badania zestaw nakładów i rezultatów jest zróżnicowany. W przypadku badania działalności edukacyjnej uczelni może to być: liczba studentów, liczba absolwentów, liczba kadry akademickiej, nakłady ponoszone na nauczanie oraz szereg innych. Podstawowym problemem w modelach oceniających nauczanie jest to, co należy uznać za rezultaty. W literaturze opinie na ten temat są podzielone. Trwa dyskusja, czy miernikiem rezultatów nauczania jest liczba studentów, czy liczba absolwentów (Carrington, O’Donnell i Prasada Rao 2018). Niektóre badania wykorzystują liczbę absolwentów (np. Agasisti i Johnes 2009; Worthington i Lee 2008; Carrington, Coelli i Prasada Rao 2005), natomiast inne używają w tym celu liczby studentów (np. Johnes i Tone 2017; Agasisti i Salerno 2007; Johnes 2006).

Liczba absolwentów, jako rezultat procesu nauczania, jest czasem krytykowana. Carrington, Coelli i Prasada Rao (2005) stwierdzają, że w mniej prestiżowych uniwersytetach przyjmuje się studentów z niższymi ocenami na wejściu, a zatem może być mniej prawdopodobne, że zakończą oni studia uzyskaniem dyplomu. Istnieje też prawdopodobieństwo tego, że słabsze uczelnie mogą obniżać swoje standardy oceniania, aby uzyskać lepsze wskaźniki ukończenia studiów (completion rates). Dodatkowo zwraca się uwagę, że należy uwzględniać podział na studentów kierunków ścisłych (science), medycznych i studentów innych kierunków, co pozwala na odzwierciedlenie zróżnicowania nakładów pracy studentów (Carrington, Coelli i Prasada Rao 2005). Natomiast Worthington i Lee (2008) stwierdzają, że bez wątpienia liczby licencjackich i magisterskich dyplomów są miarą rezultatów dla każdej uczelni.

Agasisti i Johnes (2009) w modelu DEA oceny włoskich uniwersytetów po stronie nakładów uwzględnili liczbę studentów, a po stronie rezultatów liczbę absolwentów. W obu przypadkach osobno dla pierwszego i drugiego stopnia studiów. Podobnie definiują model efektywności szwedzkich szkół wyższych Andersson i in. (2017), stwierdzając, że jednym z najważniejszych nakładów uczelni jest liczba studentów pierwszego i drugiego stopnia. Z punktu widzenia efektywności instytucji edukacyjnych ważna jest proporcja, z jaką przyjęci studenci są konwertowani na absolwentów. Może to być zróżnicowane w poszczególnych uczelniach ze względu na różnice we wskaźnikach rezygnacji oraz w standardowej długości studiów (Agasisti i Johnes 2009).

Masowe szkolnictwo wyższe wymaga dwutorowych działań koncentrujących się, z jednej strony, na zwiększaniu dostępności (co jest wejściem do systemu) oraz, 
z drugiej, na dbaniu o wysoki wskaźnik ukończenia studiów (co jest wyjściem z systemu). W tym kontekście uczelnie nie tylko powinny skupiać się na tym, aby mieć coraz większą liczbę studentów, ale także troszczyć się o to, aby ci studenci ukończyli swoje studia, najlepiej w nominalnym czasie trwania wybranego przez nich kursu (EACEA-Eurydice 2015).

\subsection{Wpływ jakości kandydatów na osiągnięcie sukcesu na studiach}

Jak wspomniano we wstępie, aspekty jakościowe procesu nauczania w uczelniach muszą być uwzględniane w badaniach ich funkcjonowania i to pomimo trudności w formułowaniu mierników. Osiągnięcie sukcesu na studiach, czyli uzyskanie dyplomu, wymaga dobrego przygotowania kandydatów. Agasisti i Salerno (2007) wykorzystali jako proxy dla jakości kształcenia odsetek studentów pierwszego roku, którzy uzyskali najlepsze wyniki w szkole średniej, co jest miernikiem ukierunkowanym na wejście pozwalającym pośrednio zmierzyć poziom przygotowania kandydatów do studiowania. Podobnie Tran, Carolyn-Dung i Villano (2017) w badaniach wietnamskich uniwersytetów, aby uwzględnić jakość przyjętych studentów, po stronie nakładów wykorzystali średnie oceny krajowych egzaminów wstępnych. Jednakże nie w każdym przypadku tego typu dane są dostępne.

Uczelnie mogą zdecydować się na selekcyjny charakter pierwszego roku, aby zwiększyć wskaźnik ukończenia i uzyskać lepsze oceny jakości przeprowadzane przez instytucje akredytacyjne. Rzeczywiście, podczas gdy niektóre uniwersyteckie programy pozwalają większości studentów zapisać się na drugi rok, inne programy starają się wybrać tylko najlepszych studentów, którzy rozpoczynają drugi rok, wprowadzając wysokie standardy oceniania. W konsekwencji wybór ten ma duży wpływ na wskaźniki rezygnacji między pierwszym a drugim rokiem. To z kolei wpływa na poziom jakości i wskaźniki ukończenia studiów (Sneyers i De Witte 2017).

Na wskaźniki ukończenia studiów mogą mieć wpływ zarówno selekcja w trakcie procesu kształcenia, jak i selekcja w procedurach przyjmowania kandydatów. Jeśli chodzi o tę ostatnią, w krajach o bardziej selekcyjnych procedurach przyjmowania sukces studentów może być wyższy niż w krajach o otwartym dostępie do wyższej edukacji (EACEA-Eurydice 2015).

\subsection{Wskaźnik ukończenia studiów}

Analizy dotyczące szkolnictwa wyższego są czasem kwestionowane ze względu na brak uwzględniania czynników jakościowych. Dotyczy to w szczególności problemu, jak uwzględniać jakość i czy może być ona przedstawiona za pomocą miar ilościowych. Daraio, Bonaccorsi i Simar (2015b) stwierdzają, że istnieje pełna zgodność, iż dane dotyczące ukończenia studiów są akceptowalnym wskaźnikiem jakości. 
Wskaźnik ukończenia przedstawia udział studentów, którzy rozpoczynają studia i uzyskują dyplom w programach wyższego kształcenia, jest on wyrażony jako procent wszystkich rozpoczynających uczestników. Brak jest jednej wspólnej metodyki międzynarodowej obliczania tego wskaźnika. True cohort method (metoda kohortowa) daje najdokładniejsze wyniki, ale jest bardzo wymagająca pod względem danych, ponieważ konieczne jest posiadanie danych panelowych (ankiet lub rejestrów), w których indywidualny student jest śledzony przez system od wejścia do ukończenia uczelni lub rezygnacji ze studiów. Badania takie prowadzone są rzadko i z reguły dotyczą studentów pierwszego stopnia. W przypadku braku takich danych wskaźnik bazuje na metodzie przekrojowej, w której liczba absolwentów w danym roku jest dzielona przez liczbę osób nowoprzyjętych do tych programów określoną liczbę lat wcześniej (EACEA-Eurydice 2015; Luca, Verdyck i Coppens 2014; Thomas i Hovdhaugen 2014). Przykładowo w wielu krajach przyjmuje się jako wskaźnik sukcesu studiowania ukończenie studiów w ciągu nominalnego okresu trwania programu plus jeden dodatkowy rok (Vossensteyn i in. 2015). Według OECD (2013) wskaźnik ukończenia jest to stosunek liczby studentów, którzy ukończyli studia w danym roku do liczby nowych uczestników na tym kursie $n$ lat wcześniej, gdzie $n$ to liczba lat studiów stacjonarnych wymaganych do uzyskania dyplomu.

Wskaźnik ukończenia może też być określony jako udział studentów uniwersytetu osiągających swój cel edukacyjny. Przykładowo dla czteroletniego programu wskaźnik ukończenia studiów obejmuje studentów, którzy uzyskali dyplom w okresie sześciu lat od rozpoczęcia programu (Lukman, Krajnc i Glavic 2010). Jeszcze inny sposób zaproponowali Sneyers i De Witte (2017), którzy wskaźnik ukończenia mierzą jako odsetek studentów, którzy pomyślnie przeszli pierwszy rok i uzyskali dyplom z maksymalnym opóźnieniem jednego roku (wskaźnik ukończenia studiów nie uwzględnia osób, które zrezygnowały w trakcie pierwszego roku).

Obserwuje się, że studenci stacjonarni (full-time) mają większe szanse na ukończenie studiów niż studenci niestacjonarni (part-time) (OECD 2013). Na przykład wysoką różnicę pomiędzy studentami studiów stacjonarnych i niestacjonarnych obserwuje się w Nowej Zelandii, gdzie wskaźnik ukończenia studiów pierwszego stopnia na studiach stacjonarnych jest o 34 punkty procentowe większy niż na studiach niestacjonarnych.

Ponieważ dane na temat wskaźników ukończenia i rezygnacji są wciąż rzadkością wśród systemów szkolnictwa wyższego w EHEA, można dokonać porównania wskaźników rekrutacji i ukończenia mierzonych w tym samym roku akademickim. Takie porównanie jest traktowane jako proxy dla postępu edukacyjnego, którego wyniki mogą być wykorzystane jako informacje pomocnicze do oceny rezultatów edukacyjnych. Zaletą porównania wskaźników wejścia i ukończenia jest to, że dane są dostępne dla znacznie większej liczby krajów, co jest istotne dla porównań międzynarodowych 
(EACEA-Eurydice 2015). Zastosowanie tej metody może jednak dać bardzo obciążone wyniki w przypadku niestabilnej liczby osób przyjmowanych na studia w kolejnych latach. Przykładem ilustrującym ten problem może być zmiana w zasadach finansowania polskich uczelni publicznych, która wymusiła w wielu przypadkach radykalne zmniejszenie liczby przyjmowanych studentów.

Luca, Verdyck i Coppens (2014) podkreślają, że ważne są też wskaźniki terminowego uzyskania dyplomu, które zależą od nominalnego czasu trwania studiów. W Stanach Zjednoczonych wszystkie instytucje edukacji wyższej są zobowiązane przez prawo do publikowania informacji o wskaźnikach ukończenia. Jednakże są dwie główne trudności w powszechnym stosowaniu wskaźników ukończenia: brak kompleksowych źródeł danych i brak konsensusu w sprawie definicji koncepcyjnej i technicznej dotyczącej wskaźników ukończenia (Luca, Verdyck i Coppens 2014).

Archibald i Feldman (2008) stwierdzają natomiast, że skupianie się na wskaźnikach ukończenia może być fałszywym rozumowaniem. Nie jest realne, aby każda uczelnia dążyła do 100\% wskaźnika ukończenia studiów. Podkreślają, że dla niektórych studentów najlepszym wyborem jest opuszczenie uczelni przed zakończeniem kursu, ponieważ dla nich zwroty z rezygnacji przekraczają zwroty z pozostania w systemie edukacji. Pomimo najlepszych starań instytucji 100\% wskaźnik ukończenia studiów nie jest ani prawdopodobny, ani społecznie optymalny. Tak więc projektowanie strategii uczelni mające na celu maksymalizowanie wskaźnika ukończenia nie zawsze byłoby dobrą decyzją edukacyjną, ponieważ uczelnie mogłyby osiągnąć wyższy wskaźnik ukończenia poprzez obniżenie standardów oceniania lub popieranie zwiększającej się inflacji uzyskiwanych dyplomów. Każda uczelnia z pewnością mogłaby również osiągnąć wyższe wskaźniki ukończenia poprzez ograniczenie dostępu studentów tylko do tych, którzy są pewni jej ukończenia. Podniesienie wskaźnika ukończenia studiów na te dwa ostatnie sposoby oczywiście nie jest społecznie użyteczne, ponieważ osłabiłoby to zobowiązanie wielu krajów do szerokiego dostępu do edukacji wyższej.

\subsection{Wskaźnik rezygnacji ze studiów}

Wskaźnik rezygnacji pomiędzy pierwszym a drugim rokiem kursu akademickiego pośrednio odwzorowuje brak satysfakcji z podjętych studiów, chociaż studenci mogą też rezygnować z innych powodów (Agasisti i Salerno 2007). Zdając sobie sprawę, że przejście z pierwszego do drugiego roku studiów jest kluczowym etapem ścieżki edukacyjnej studentów, część krajów w swojej polityce edukacji uniwersyteckiej koncentruje się właśnie na retencji (lub rezygnacji) w czasie trwania pierwszego roku studiów (Vossensteyn i in. 2015).

Sneyers i De Witte (2017) zaobserwowali, że niektóre programy akademickie łączą niskie wskaźniki rezygnacji w pierwszym roku z wysokimi wskaźnikami ukończenia 
studiów. Inne programy traktują pierwszy rok studiów jako bardziej selekcyjny, co oznacza ostrzejsze standardy oceniania i łączą wysokie wskaźniki rezygnacji w trakcie pierwszego roku z wysokimi wskaźnikami ukończenia studiów tych studentów, którzy przeszli na drugi rok. Jednak niektóre programy akademickie o wysokim wskaźniku rezygnacji w trakcie pierwszego roku nie osiągają wysokich wskaźników ukończenia. Byłoby interesujące zidentyfikowanie cech programowych i instytucjonalnych, które w przypadku określonych poziomów rezygnacji prowadzą do wysokiej stopy dyplomowania, jednakże jest to niemożliwe z powodu braku wiarygodnych danych.

Barra i Zotti (2016) potwierdzają doświadczenia innych autorów, że przejście z pierwszego do drugiego roku jest uznawane za jedną ze słabości włoskiego systemu szkolnictwa wyższego. System ten był często krytykowany ze względu na jego nieefektywność pod względem niskiej liczby zapisów, wysokiego wskaźnika rezygnacji, nadmiernej rzeczywistej długości studiów. W latach 2002-2009 średnio 20.35\% studentów włoskich uczelni nie zapisało się na drugim roku. Biorąc pod uwagę ten sam przedział czasowy, 18.02\% studentów uważa się za nieaktywnych, co oznacza, że studenci nie uzyskali żadnych punktów w ciągu pierwszego roku studiów. Zdaniem przywołanych autorów przy ocenie wyników uczelni konieczne jest uwzględnienie tego wskaźnika.

Agasisti i Salerno (2007) w swojej ocenie efektywności kosztowej włoskich uniwersytetów zastosowali wskaźnik rezygnacji ze studiów jako miarę jakości kształcenia przy założeniu, że jakość jest najlepiej odwzorowana przez zadowolenie tych, którzy faktycznie uczestniczą w systemie edukacji.

Na to, że studenci rezygnują z kontynuowania studiów między pierwszym a drugim rokiem, może mieć wpływ wiele czynników związanych z funkcjonowaniem wyższych uczelni i indywidualnymi studentami. Na poziomie indywidualnym może to być niewłaściwy wybór programu lub kierunku studiów, niewystarczająca motywacja do sprostania wymaganiom programu nauczania, a także szeroka gama innych ograniczeń, w tym barier finansowych, problemów zdrowotnych i powodów rodzinnych. Na poziomie uczelni mogą to być bariery strukturalne i instytucjonalny brak elastyczności, na przykład niemożność zaspokojenia potrzeb coraz bardziej heterogenicznej populacji studentów, co może wzmocnić indywidualne ryzyko rezygnacji. Studenci pierwszego roku są najbardziej podatni na porzucanie studiów, jeśli zbyt mało uwagi poświęca się ich pierwszym doświadczeniom i rozwojowi umiejętności (EACEA-Eurydice 2015).

Rezygnacja ze studiów nie musi oznaczać całkowitego niepowodzenia poszczególnych studentów, ale wysokie wskaźniki rezygnacji mogą wskazywać, że system edukacji nie zaspokaja potrzeb swoich klientów. Studenci mogą też stwierdzać, że oferowane programy edukacyjne nie spełniają ich oczekiwań lub potrzeb rynku 
pracy, na którym będą poszukiwać zatrudnienia. Inna przyczyna to stwierdzenie, że programy trwają dłużej niż czas przewidziany przez studentów na studiowanie, a tym samym przebywanie poza rynkiem pracy (OECD 2004).

Studenci mogą podjąć decyzję o opuszczeniu systemu edukacji przed ukończeniem studiów, ponieważ w niektórych krajach oferowane będą atrakcyjne możliwości zatrudnienia po zaledwie jednym roku studiów. Podobnie niektórzy płacący za naukę studenci, którzy rozpoczynają wyższe studia, na przykład w Nowej Zelandii czy Szwecji, nie zamierzają ukończyć w całości konkretnego programu, ale raczej wybierają kilka kursów w ramach uczenia się przez całe życie lub podnoszenia kwalifikacji (OECD 2013).

\subsection{Wskaźnik liczby studentów do liczby nauczycieli}

Wskaźnik ukończenia studiów i wskaźnik rezygnacji ze studiów mają w modelach oceny efektywności charakter rezultatów. W pierwszym przypadku jest to rezultat pożądany, a w drugim niepożądany, co zostaje uwzględnione w zastosowaniu odpowiedniego modelu DEA. Jakość kandydatów ma charakter nakładu. Innym wskaźnikiem wejściowym jest liczba studentów przypadająca na jednego nauczyciela. Podobnie jak pozostałe omówione wyżej wskaźniki nie jest on jednoznacznie interpretowany przez różnych autorów.

Według Daraio, Bonaccorsi i Simar (2015a) systemy szkolnictwa wyższego w krajach rozwiniętych osiągnęły poziom masowości (tzn. stopa rekrutacji przekracza 50\% odpowiedniej dla studiowania kohorty wiekowej), podczas gdy finansowanie szkolnictwa wyższego nie wzrosło w odpowiednim stopniu. Stąd uniwersytety są pod presją wykorzystywania w jak najbardziej efektywny sposób posiadanych zasobów. Duża liczba studentów przy ograniczeniu zasobów finansowych powoduje, że pogarsza się relacja między liczbą studentów a liczbą nauczycieli akademickich. W tym kontekście wskaźnikiem, w pośredni sposób odzwierciedlającym jakość procesu kształcenia, jest powszechnie stosowany stosunek liczby studentów do liczby kadry akademickiej (np. Zrelli i Hamida 2013; Murias, de Miguel i Rodriguez 2008). Zakłada się, że im mniejsza liczba studentów, za których odpowiada nauczyciel akademicki, tym wyższa będzie jakość jego pracy, bo może poświęcić więcej czasu dla każdego studenta.

Część autorów traktuje jednak stosunek liczby studentów do liczby kadry akademickiej bardziej jako wskaźnik dostępności zasobów dydaktycznych, które studenci mogą uzyskać w uczelniach, a więc nie jest on wprost miernikiem jakości. Zapewnia ogólną ocenę działań uniwersytetów dla zapewnienia studentom szerszego osobistego kontaktu z nauczycielami akademickimi (Lukman, Krajnc i Glavic 2010). Według OECD (2004) stosunek liczby studentów do liczby nauczycieli akademickich to miernik dostępności studentów do nauczycieli, którzy są najważniejszymi zasobami 
w procesie nauczania. Jednakże niska wartość tego wskaźnika niekoniecznie oznacza lepsze wsparcie edukacyjne a może być po prostu symptomem nieefektywnego wykorzystania zasobów ludzkich. Z kolei bardzo wysoka wartość tego wskaźnika z pewnością wskazuje na niewystarczające profesjonalne wsparcie studentów w nauczaniu. Podkreśla się, że takie wnioskowanie trzeba przeprowadzać z dużą ostrożnością, ponieważ wiele innych czynników również wpływa na jakość procesu nauczania i efekty uczenia się.

\section{Metodyka badań}

Data Envelopment Analysis (DEA) jest metodą szeroko stosowaną w badaniach efektywności systemów edukacji wyższej. Jest to metoda nieparametryczna wykorzystująca programowanie liniowe, która pozwala na określenie efektywności względnej zestawu obiektów zwanych Decision Making Units (jednostkami decyzyjnymi - DMU). Pomiar efektywności polega na określaniu relacji między wieloma nakładami i wieloma rezultatami funkcjonowania danego obiektu w kontekście sformułowanego celu badania. Wyznacza się obiekty wzorcowe, które tworzą granicę dobrych praktyk i przyrównuje się do nich obiekty pozostałe. Wagi optymalne przypisywane do poszczególnych nakładów i rezultatów są obliczane endogennie, na podstawie danych, a nie są ustalane subiektywnie (Cooper, Seiford i Tone 2007).

Najbardziej ogólnie rzecz biorąc, modele stosowane w DEA można podzielić na dwie grupy: radialne i nieradialne. Dwa podstawowe, najczęściej stosowane modele radialne, czyli CCR (od nazwisk twórców: Charnes, Cooper i Rhodes) ze stałymi efektami skali i BCC (od nazwisk twórców: Banker, Charnes i Cooper) ze zmiennymi efektami skali, pozwalają na obliczenie efektywności technicznej, czystej efektywności technicznej i efektywności skali (Cooper, Seiford i Tone 2007). Oceniają one radialną (proporcjonalną) efektywność, nie uwzględniają jednakże nadwyżek nakładów oraz niedoborów rezultatów (tzw. luzów). Zgodnie z definicją efektywności DEA funkcjonowanie DMU jest w pełni (w 100\%) efektywne, wtedy i tylko wtedy, gdy zarówno wynik efektywności jest równy jedności oraz nadwyżki nakładów i niedobory rezultatów są zerowe. Istnieje możliwość zastosowania modeli nieradialnych, które pozwalają na uwzględnienie luzów bezpośrednio w obliczeniach efektywności (Cooper, Seiford i Zhu 2011). Kolejną istotną kwestią w doborze rodzaju modelu jest jego orientacja na nakłady lub na rezultaty. Jest to uzależnione od tego, czy w badaniach istotne jest minimalizowanie nakładów przy zachowaniu wolumenu rezultatów, czy maksymalizowanie rezultatów przy zachowaniu poziomu nakładów. Orientacja uzależniona jest również od tego, czym decydenci mogą sterować (Cook, Tone i Zhu 2014). 
W zależności od celu badania struktura wykorzystywanych modeli jest zróżnicowana, zarówno w zakresie stosowanych algorytmów, jak i zestawu nakładów i rezultatów. W przypadkach stosowania modeli radialnych, gdy mamy do czynienia z niepożądanymi rezultatami, luzy w takich sytuacjach nie są uwzględniane w obliczaniu miar efektywności. Z drugiej strony, w przypadku modeli zorientowanych na nakłady (lub rezultaty) skupiają się one jedynie na efektywności po stronie nakładów (lub rezultatów), a strona rezultatów (lub nakładów) jest drugorzędnym przedmiotem pomiaru efektywności. Dlatego tylko modele nieradialne i niezorientowane mogą uwzględnić wszystkie aspekty efektywności (Cooper, Seiford i Tone 2007).

Wyniki badań przeprowadzonych przez Johnes i Tone (2017) wskazują, że wyniki uzyskiwane z zastosowań DEA są wysoce wrażliwe na to, jaka metodyka jest wybrana. W związku z tym konieczne jest dobranie właściwego modelu i zachowanie ostrożności przy interpretacji wyników.

W artykule zastosowano więc miarę efektywności bazującą na luzach (Slack Based Measure, SBM), która dopuszcza niepożądane rezultaty. Przyjmuje ona wartości z przedziału [o, 1], eliminując niezerowe luzy nakładów i rezultatów. Model [SBM-Undesirable] (Cooper, Seiford i Tone 2007; Tone, 2001) zakłada, że jest $n$ DMU, z których każda ma trzy składowe: nakłady, pożądane rezultaty i niepożądane rezultaty, reprezentowane odpowiednio przez trzy wektory $\boldsymbol{x} \in R^{m}, \boldsymbol{y}^{g} \in R^{s_{1}}$ i $\boldsymbol{y}^{b} \in R^{s_{2}}$. Definiowane są macierze $\boldsymbol{X}, \boldsymbol{Y}^{g}$ i $\boldsymbol{Y}^{b}$ jak następuje: $\boldsymbol{X}=\left[\boldsymbol{x}_{1}, \ldots, \boldsymbol{x}_{n}\right] \epsilon R^{m \times n}, \boldsymbol{Y}^{g}=\left[\boldsymbol{y}_{1}^{g}\right.$, $\left.\ldots, \boldsymbol{y}_{n}^{g}\right] \epsilon R^{s_{1} \times n}$ i $\boldsymbol{Y}^{b}=\left[\boldsymbol{y}_{1}^{b}, \ldots, \boldsymbol{y}_{n}^{b}\right] \epsilon R^{s_{2} \times n}$. Zakłada się, że $, \boldsymbol{X}>\mathbf{o}, \boldsymbol{Y}^{b}>\mathbf{o} \boldsymbol{Y}^{g}>\mathbf{0}$.

Zbiór możliwości produkcyjnych $(P)$ jest definiowany przez:

$$
P=\left\{\left(\boldsymbol{x}, \boldsymbol{y}^{g}, \boldsymbol{y}^{b}\right) \mid \boldsymbol{x} \geq \boldsymbol{X} \boldsymbol{\lambda}, \boldsymbol{y}^{g} \leq \boldsymbol{Y}^{g} \boldsymbol{\lambda}, \boldsymbol{y}^{b} \geq \boldsymbol{Y}^{b} \lambda, \lambda \geq \mathbf{0}\right\}
$$

gdzie: $\lambda \in R^{n}$ jest wektorem intensywności.

$D M U_{o}\left(\boldsymbol{x}_{0}, \boldsymbol{y}_{0}^{g}, \boldsymbol{y}_{0}^{b}\right)$ jest efektywna, przy założeniu istnienia niepożądanych rezultatów, jeżeli nie istnieje wektor $\left(\boldsymbol{x}, \boldsymbol{y}^{g}, \boldsymbol{y}^{b}\right) \in P$ taki, że $\boldsymbol{x}_{0} \geq \boldsymbol{x}, \boldsymbol{y}_{0}^{g} \leq \boldsymbol{y}^{g}$ i $\boldsymbol{y}_{0}^{b} \geq \boldsymbol{y}^{b}$, $\mathrm{z}$ co najmniej jedną ostrą nierównością.

Zgodnie z tą definicją model [SBM-Undesirable] przyjmuje postać:

Z warunkami:

$$
\rho^{*}=\min \frac{1-\frac{1}{m} \sum_{i=1}^{m} \frac{s_{i}^{-}}{x_{i o}}}{1+\frac{1}{s_{1}+s_{2}}\left(\sum_{r=1}^{s_{1}} \frac{s_{r}^{g}}{y_{r o}^{g}}+\sum_{r=1}^{s_{2}} \frac{s_{r}^{b}}{y_{r o}^{b}}\right)}
$$

$$
\begin{aligned}
& \boldsymbol{x}_{\mathrm{o}}=\boldsymbol{X} \boldsymbol{\lambda}+\boldsymbol{s}^{-} \\
& \boldsymbol{y}_{0}^{g}=\boldsymbol{Y}^{g} \boldsymbol{\lambda}-\boldsymbol{s}^{g} \\
& \boldsymbol{y}_{0}^{b}=\boldsymbol{Y}^{b} \boldsymbol{\lambda}-\boldsymbol{s}^{b} \\
& \boldsymbol{s}^{-} \geq \mathbf{0}, \boldsymbol{s}^{g} \geq \mathbf{0}, \boldsymbol{s}^{b} \geq \mathbf{0}, \boldsymbol{\lambda} \geq \mathbf{0}
\end{aligned}
$$


Wektory $\boldsymbol{s}^{-} \epsilon R^{m}$ i $\boldsymbol{s}^{b} \epsilon R^{s_{2}}$ odpowiadają odpowiednio nadwyżkom w nakładach i niepożądanych rezultatach, podczas gdy $\boldsymbol{s}^{g} \in R^{s_{1}}$ odzwierciedla niedobory w pożądanych rezultatach. Funkcja celu (2) jest ściśle malejąca w odniesieniu do $s_{i}^{-}(\forall i), s_{r}^{g}(\forall r)$ i $s_{i}^{b}(\forall r)$, i wartości funkcji celu spełniającej warunek $0<\rho^{*} \leq 1$. Jeżeli optymalnym rozwiązaniem powyższego problemu będzie $\boldsymbol{\lambda}^{*}, \boldsymbol{s}^{-*}, \boldsymbol{s}^{g^{*}}, \boldsymbol{s}^{b^{*}}$, wtedy można stwierdzić, że $D M U_{\text {o }}$ jest efektywna przy obecności niepożądanych rezultatów wtedy i tylko wtedy, gdy $\rho^{*}=1$, to znaczy, gdy: $\boldsymbol{s}^{\boldsymbol{-}^{*}}=\mathbf{o}, \boldsymbol{s}^{g^{*}}=\mathbf{0}$ i $\boldsymbol{s}^{b^{*}}=\mathbf{0}$.

Aby uzyskać ranking jednostek efektywnych, można wykorzystać model super efektywności (Super-Efficiency) (Cooper, Seiford i Zhu 2011). Aby uzyskać taki ranking, podstawowy model rozszerza się o dodatkowy warunek pozwalający na porównanie obiektu ocenianego $D M U_{o}$ z liniową kombinacją wszystkich pozostałych obiektów w próbce poprzez wyłączenie tego obiektu z oceny (przy sumowaniu w trzech pierwszych warunkach równań (3) należy wprowadzić korektę zakresu sumowania postaci: $j=1 \ldots n, j \neq 0$ ).

Warto jeszcze zwrócić uwagę na jeden problem dotyczący doboru danych, który wynika ze specyfiki problemu poruszanego w artykule. Konwencjonalne modele DEA zakładają (Lee, Zhang i Jeong 2016), iż nakłady poniesione w danym okresie są wykorzystywane do produkcji rezultatów w tym samym okresie. Jednakże w niektórych zastosowaniach nakłady z pewnego okresu mogą przyczyniać się do rezultatów w innych okresach. Określa się to jako opóźnienie czasowe (time lag), które wpływa w istotny sposób na wyniki oceny efektywności. Przykładem może być publikowanie artykułów naukowych i zgłaszanie patentów, które są ważnymi rezultatami działalności badawczej, ale są one zawsze wynikiem wysiłków badawczych trwających przez kilka poprzedzających lat. W przypadku działalności badawczej długość czasu opóźnienia jest niepewna i zależy od obszarów, które podlegają ocenie, natomiast w przypadku problemu rozważanego w tym artykule można to określić na podstawie długości cyklu edukacyjnego: od momentu rozpoczęcia nauki do chwili uzyskania dyplomu ukończenia studiów.

\section{Opis danych i dobór zmiennych}

Do analizy wybrano grupę polskich uczelni technicznych. Zgodnie z klasyfikacją Ministerstwa Nauki i Szkolnictwa Wyższego (MNiSW) działa w Polsce 18 publicznych uczelni o profilu technicznym: Politechniki Białostocka, Częstochowska, Gdańska, Koszalińska, Krakowska, Lubelska, Łódzka, Opolska, Poznańska, Rzeszowska, Śląska, Świętokrzyska, Warszawska, Wrocławska oraz Akademia Górniczo-Hutnicza, Akademia Techniczno-Humanistyczna w Bielsku-Białej, Uniwersytet Technologiczno-Humanistyczny im. Kazimierza Pułaskiego w Radomiu, Zachodniopomorski Uniwersytet Technologiczny. Wszystkie są szkołami publicznymi, które funkcjonują 
w oparciu o te same przepisy, prowadzą zbliżone zestawy kierunków studiów, mają na celu głównie kształcenie inżynierów i rozwój nauki w dziedzinach technicznych. Pomimo pewnego zróżnicowania ich wielkości i zestawu prowadzonych kierunków studiów z racji deklarowanego, dominującego profilu technicznego można je traktować jako jednorodną grupę.

Wykorzystano dane z lat 2011, 2012 i 2015 pochodzące z Głównego Urzędu Statystycznego (GUS) oraz MNiSW. Dobór zmiennych przeprowadzono w oparciu o przedstawioną wcześniej analizę literatury. Ponieważ dla polskich uczelni nie zbiera się podstawowych danych o wskaźnikach rezygnacji, wskaźnikach ukończenia studiów czy liczbie studentów na nauczyciela, poniżej zostały przedstawione proxy dla tych zmiennych obliczone na podstawie dostępnych danych.

Jako punkt wyjścia przyjęto liczbę absolwentów, którzy ukończyli studia pierwszego stopnia i uzyskali dyplomy w roku 2015 (ABS_2015). Biorąc pod uwagę to, że studia o profilu technicznym trwają zwykle 3.5 roku na studiach stacjonarnych i 3.5-4 lata na studiach niestacjonarnych, przyjęto, że absolwenci z roku 2015 rozpoczynali studia w roku 2011 (STUD_I_ROK_2011). Oczywiście jest to wartość przybliżona, ponieważ w tej grupie absolwentów mogą być również osoby, które z różnych przyczyn (np. przerwy w nauce czy powtarzania roku) mogły rozpocząć studia wcześniej. Odnosząc liczbę absolwentów do liczby rozpoczynających studia, można oszacować wskaźnik ukończenia studiów (UKONCZ_2011=ABS_2015 / STUD_I_ROK_2011). Jeżeli w analizie uwzględnia się liczbę studentów, którzy zrezygnowali ze studiów między pierwszym a drugim rokiem, wskaźnik ukończenia studiów powinien być obliczany względem studentów, którzy przeszli pomyślnie pierwszy rok i zostali zarejestrowani na rok drugi (jest to liczba studentów studiujących na drugim roku w 2012 roku) (W1=ABS_2015 / STUD_II_ROK_2012). Dane o liczbie nowoprzyjętych studentów w roku 2011 są dostępne (PRZYJ_2011), podobnie rzecz ma się z danymi o liczbie studentów studiujących na pierwszym roku (STUD_I_ROK_2011). Te dwie wartości różnią się, ponieważ niektóre uczelnie dopuszczają powtarzanie pierwszego roku. $\mathrm{Na}$ tej podstawie wyliczono liczbę powtarzających pierwszy rok studiów (W4= STUD_I_ROK_2011 - PRZYJ_2011).

Kolejnym istotnym problemem jest przedstawianie w statystykach GUS i MNiSW liczby studentów na poszczególnych latach studiów łącznie dla pierwszego stopnia i jednolitych studiów magisterskich. Uczelnie techniczne nie prowadziły w badanym okresie studiów jednolitych, co pozwala na przeprowadzenie tej analizy. Jednakże taki sposób prezentowania danych eliminuje możliwość dołączenia do analizy uniwersytetów, ponieważ nie ma możliwości określenia liczby studentów pierwszego stopnia. Różnica między liczbą studentów studiujących na pierwszym roku w roku 2011 i studentów studiujących na drugim roku 
w roku 2012 jest przybliżeniem liczby studentów, którzy zrezygnowali ze studiów (REZYGN= STUD_I_ROK_2011 - STUD_II_ROK_2012) bądź w niektórych uczelniach zostali skierowani na powtarzanie pierwszego roku. Wskaźnik rezygnacji to bezwzględna liczba rezygnacji odniesiona do liczby studentów pierwszego roku w roku 2011 (W2= REZYGN / STUD_I_ROK_2011). W danych MNiSW są informacje na temat liczby nauczycieli akademickich w przeliczeniu na pełne etaty (KADRA), więc istnieje możliwość oszacowania wskaźnika liczby studentów na jednego nauczyciela dla wszystkich studentów uczelni (wszystkie poziomy i formy studiów) (W3=STUD_WSZYSCY / KADRA). W przypadku liczby nauczycieli również pojawia się problem, ponieważ nie są oni przypisani do rodzaju i formy studiów, więc mogą prowadzić zajęcia zarówno na studiach pierwszego i drugiego stopnia, na studiach stacjonarnych i niestacjonarnych. W artykule przyjęto, że do studiów pierwszego stopnia przypisano liczbę nauczycieli proporcjonalnie do udziału studentów pierwszego stopnia w całkowitej liczbie studentów (KADRA_I_ST=STUD_I_ST / W3).

W proponowanym modelu, aby uwzględnić wielkość uczelni, przyjęto całkowitą liczbę studentów studiów stacjonarnych i niestacjonarnych pierwszego stopnia (STUD_I_ST). De Witte i Hudrlikova (2013) stwierdzają, że wielkość uczelni może być wyrażona jako liczba zapisanych studentów lub liczba jednostek organizacyjnych (wydziałów i katedr). Oba te wskaźniki wielkości są w dużym stopniu egzogenne dla uniwersytetów.

Dodatkowo w analizie wykorzystano udział studentów stacjonarnych studiów pierwszego stopnia (W5) i udział studentów na kierunkach technicznych na studiach pierwszego stopnia (W6).

Zdefiniowane wyżej wskaźniki W1-W6 są wykorzystane do wstępnej analizy wskaźnikowej oraz przy interpretacji wyników z modelu DEA.

Liczba zmiennych użytych w modelu DEA musi być ograniczona ze względu na siłę dyskryminacji, która maleje wraz ze wzrostem liczby zmiennych. Ważna jest relacja między liczbą ocenianych DMU a lączną liczbą zmiennych określających nakłady i rezultaty. Sugerowana jest praktyczna zasada (rule of thumb) (Cook, Tone i Zhu 2014) mówiąca o tym, że liczba uwzględnianych w analizie DMU powinna być przynajmniej trzy razy większa niż łączna liczba nakładów i rezultatów. Takie reguły nie mają charakteru nakazu ani nie mają podstaw statystycznych, lecz są one wynikiem praktycznych doświadczeń.

Dla przypadku omawianego w artykule przy 18 uczelniach liczba zmiennych nie powinna przekraczać pięciu. Tak więc tylko część zmiennych została wykorzystana bezpośrednio w modelu, a reszta wykorzystana jest do interpretacji wyników.

Ponieważ stosowanie zmiennych wskaźnikowych (ratio measures) w DEA jest dyskusyjne (np. Olesen, Petersen i Podinovski 2015), zastosowano surowe dane 
wykorzystane do tworzenia wskaźników. Ostatecznie model składa się z trzech nakładów i dwóch rezultatów.

Nakłady:

1. STUD_I_ROK_2011 - liczba studentów studiów pierwszego stopnia w roku 2011 (nowoprzyjęci i powtarzający pierwszy rok);

2. KADRA_I_ST - liczba nauczycieli akademickich przypisanych do studiów pierwszego stopnia;

3. STUD_I_ST - całkowita liczba studentów pierwszego stopnia.

Rezultaty:

4. ABS_2015 - liczba osób, które w roku 2015 ukończyły studia, uzyskując dyplom licencjata lub inżyniera (rezultat pożądany);

5. REZYGN - liczba studentów, którzy zrezygnowali ze studiów między pierwszym a drugim rokiem studiów (rezultat niepożądany).

Podstawowe statystyki opisowe zmiennych łącznie dla studiów stacjonarnych i niestacjonarnych przedstawia Tabela 1.

Tabela 1. Podstawowe statystyki opisowe zmiennych

\begin{tabular}{|l|l|l|l|l|l|}
\hline Zmienna & $\begin{array}{l}\text { STUD_I_ } \\
\text { ROK_2011 }\end{array}$ & KADRA_I_ST & STUD_I_ST & ABS_2015 & REZYGN \\
\hline Min & 2262 & 270 & 4420 & 1190 & 455 \\
\hline Max & 10192 & 1794 & 27150 & 5558 & 3249 \\
\hline Średnia & 4933 & 832 & 12443 & 2535 & 1278 \\
\hline Odchyl. & 2553 & 502 & 7318 & 1314 & 734 \\
\hline
\end{tabular}

Źródło: opracowanie własne.

Spełniony jest warunek izotoniczności zestawu zmiennych, czyli między nakładami i rezultatami jest statystycznie istotna dodatnia korelacja. Wartości współczynników korelacji Pearsona mieszczą się w przedziale 0.75-0.96.

\section{Wyniki i dyskusja}

Obliczenia efektywności przeprowadzono dla studiów stacjonarnych, niestacjonarnych oraz łącznie dla obu form studiowania. W pierwszym etapie zostały obliczone wskaźniki ukończenia studiów, rezygnacji ze studiów, liczby studentów przypadających na jednego nauczyciela, wskaźnik osób powtarzających pierwszy rok, wskaźnik udziału studentów stacjonarnych, wskaźnik udziału studentów na kierunkach technicznych. Wyniki przedstawione są w Tabeli 2. 
Tabela 2. Podstawowe wskaźniki charakteryzujące badane uczelnie (łącznie dla obu form studiów)

\begin{tabular}{|l|c|c|c|c|c|c|c|}
\hline & \multirow{2}{*}{ Skrót } & \multicolumn{7}{|c|}{ Wskaźniki* } \\
\cline { 4 - 8 } & & W1 & W2 & W3 & W4 & W5 & W6 \\
\hline $\begin{array}{l}\text { Akademia Górniczo-Hutnicza } \\
\text { im. St. Staszica w Krakowie }\end{array}$ & AGH & 0.75 & 0.23 & 13.62 & 0.013 & 0.83 & 0.93 \\
\hline $\begin{array}{l}\text { Akademia Techniczno-Humanistyczna } \\
\text { w Bielsku-Białej }\end{array}$ & ATH & 0.73 & 0.29 & 15.7 & 0.009 & 0.70 & 0.60 \\
\hline Politechnika Białostocka & PB & 0.62 & 0.23 & 16.26 & 0.037 & 0.83 & 0.92 \\
\hline Politechnika Częstochowska & PCz & 0.80 & 0.26 & 11.56 & 0.006 & 0.72 & 0.72 \\
\hline Politechnika Gdańska & PG & 0.62 & 0.23 & 18.91 & 0.135 & 0.91 & 0.94 \\
\hline Politechnika Koszalińska & PK & 0.67 & 0.3 & 12.86 & 0.021 & 0.76 & 0.61 \\
\hline $\begin{array}{l}\text { Politechnika Krakowska } \\
\text { im. T. Kościuszki }\end{array}$ & PKr & 0.70 & 0.20 & 13.38 & 0.025 & 0.81 & 0.98 \\
\hline Politechnika Lubelska & PL & 0.66 & 0.18 & 17.74 & 0.010 & 0.82 & 0.94 \\
\hline Politechnika Łódzka & PŁ & 0.61 & 0.33 & 14.18 & 0.067 & 0.83 & 0.93 \\
\hline Politechnika Opolska & PO & 0.68 & 0.28 & 14.80 & 0.007 & 0.81 & 0.78 \\
\hline Politechnika Poznańska & PP & 0.76 & 0.27 & 15.59 & 0.013 & 0.79 & 0.99 \\
\hline $\begin{array}{l}\text { Politechnika Rzeszowska } \\
\text { im. I. Łukasiewicza }\end{array}$ & PR & 0.75 & 0.21 & 21.45 & 0.041 & 0.80 & 0.78 \\
\hline Politechnika Śląska w Gliwicach & PŚl & 0.80 & 0.28 & 13.07 & 0.053 & 0.77 & 0.92 \\
\hline Politechnika Świętokrzyska w Kielcach & PŚw & 0.73 & 0.27 & 18.15 & 0.000 & 0.75 & 0.94 \\
\hline Politechnika Warszawska & PW & 0.63 & 0.23 & 14.14 & 0.027 & 0.81 & 0.90 \\
\hline Politechnika Wrocławska & PWr & 0.62 & 0.32 & 16.53 & 0.126 & 0.90 & 0.96 \\
\hline $\begin{array}{l}\text { Uniwersytet Technologiczno- } \\
\text { Humanistyczny im. Kazimierza } \\
\text { Pułaskiego w Radomiu }\end{array}$ & & 0.23 & 17.04 & 0.000 & 0.73 & 0.48 \\
\hline $\begin{array}{l}\text { Zachodniopomorski Uniwersytet } \\
\text { Technologiczny w Szczecinie }\end{array}$ & & 0.62 & 0.31 & 10.71 & 0.041 & 0.85 & 0.93 \\
\hline Wartość minimalna & & 0.61 & 0.18 & 10.71 & 0.00 & 0.70 & 0.48 \\
\hline Wartość maksymalna & 0.80 & 0.33 & 21.45 & 0.13 & 0.91 & 0.99 \\
\hline Wartość średnia & & 0.04 & 2.72 & 0.04 & 0.06 & 0.15 \\
\hline Odchylenie standardowe & & & & & & & \\
\hline
\end{tabular}

* - W1 - wskaźnik ukończenia liczony względem 2012 roku; W2 - wskaźnik rezygnacji po pierwszym roku; W3 - liczba studentów na nauczyciela; W4 - udział studentów powtarzających I rok studiów w roku 2011; W5 - udział studentów studiów stacjonarnych; W6 - udział studentów na kierunkach technicznych. 
Na podstawie tych prostych wskaźników można dokonać oceny funkcjonowania poszczególnych uczelni w kontekście celu sformułowanego we wstępie. Podstawową miarą sukcesu jest ukończenie studiów w nominalnym czasie ich trwania. Na studiach stacjonarnych z osób przyjętych w 2011 roku ukończyło studia terminowo od 43\% do 55\%. Zdecydowanie gorzej przedstawia się sytuacja dla studiów niestacjonarnych, które ukończyło od 24\% do 40\%. Łącznie średnio nie ukończyło studiów około 52\% studentów, czyli z 88800 studentów rozpoczynających studia w 2011 nie uzyskało terminowo dyplomu 42800 osób. Podkreślić trzeba, że te wskaźniki ukończenia nie odbiegają od wartości rejestrowanych w innych krajach.

Bardzo negatywnym zjawiskiem jest porzucanie studiów między pierwszym a drugim rokiem (wskaźnik W2). Na studiach stacjonarnych wskaźniki rezygnacji ze studiów dla badanych uczelni mieszczą się w przedziale $16-33 \%$, dla niestacjonarnych $19-48 \%$, a łącznie dla obu form studiów w przedziale $18-33 \%$. Jest to bezpośredni wynik braku selekcji przy przyjmowaniu na studia. Niektóre uczelnie chcąc wypełnić limity, przyjmują kandydatów, którzy nie mają odpowiedniego przygotowania do podjęcia studiów. W liczbach bezwzględnych we wszystkich badanych uczelniach było to 23000 osób, między rokiem 2011 a 2012. Z tym związany jest kolejny problem, który ilustrują wartości wskaźnika W4. Poszczególne uczelnie prowadzą różną politykę odnośnie stwarzania studentom możliwości powtarzania pierwszego roku. Takie uczelnie jak ATH, PCz, PL, PO, PŚw czy UTH traktują pierwszy rok selekcyjnie i praktycznie dopuszczają powtarzanie pierwszego roku tylko w szczególnych przypadkach losowych (liczba bezwzględna osób powtarzających mieści się w przedziale 0-25 osób dla całej uczelni). Inne uczelnie jak np. PG, PŁ, PŚl czy PWr pozwalają na powtarzanie w sposób bardziej liberalny (liczba bezwzględna osób powtarzających mieści się w przedziale 400-1 285 osób dla całej uczelni). Sumarycznie we wszystkich uczelniach w roku 2011 pierwszy rok studiów powtarzało 4120 studentów, z czego 3130 na studiach stacjonarnych. Przy operowaniu wartościami bezwzględnymi trzeba oczywiście brać pod uwagę wielkość uczelni, co odwzorowuje wskaźnik W4 odnoszący liczbę powtarzających do liczby studentów pierwszego roku, którego wartości mieszczą się w przedziale 0.00-0.13.

Wskaźnik W3 przedstawiający liczbę studentów przypadającą na jednego nauczyciela akademickiego, który powszechnie próbuje się wskazywać jako główny miernik jakości kształcenia, dla badanych uczelni jest skorelowany ze wskaźnikiem W1 (który uważany jest powszechnie za główny miernik sukcesu studiowania) na poziomie 0.013, czyli praktycznie nie ma żadnego wpływu. Wartości tego wskaźnika mieszczą się w przedziale 10.7-21.5. ZUT, który ma najniższą wartość tego wskaźnika równą 10.7, w rankingu DEA zajmuje jednak końcowe pozycje.

Studia niestacjonarne w badanych uczelniach, poza małymi wyjątkami, nie są prowadzone na szeroką skalę. Wskaźnik W5 określający udział studentów studiów stacjonarnych mieści się w przedziale 0.70-0.91, a więc można stwierdzić, że niektóre 
uczelnie, w tym duże takie jak PWr i PG, mają około 10\% studentów niestacjonarnych. Jednakże wskaźniki rezygnacji i ukończenia studiów dla tej grupy są w większości przypadków gorsze dla studiów niestacjonarnych.

Ponieważ przedmiotem badania są uczelnie techniczne, zgodnie z ich misją powinny one prowadzić głównie kierunki techniczne. Wskaźnik W6 przyjmuje wartości z przedziału 0.48-0.99. Takie uczelnie jak PKr czy PP śladowo prowadzą kierunki nietechniczne, natomiast takie jak ATH, PK czy UTH mają odpowiednio udział studentów na kierunkach nietechnicznych 40, 39 i 52 procent. Można zadać pytanie, czy powinny być one wliczane do uczelni technicznych?

Kolejny etap badań to obliczenie efektywności na podstawie wcześniej zdefiniowanego i opisanego zestawu zmiennych przy pomocy modelu z niepożądanymi rezultatami, który przedstawiono równaniami (2) i (3). Ponieważ jak już wcześniej zasygnalizowano, wyniki dla niektórych uczelni różnią się dla studiów stacjonarnych i niestacjonarnych, analiza została przeprowadzona osobno dla tych dwóch form studiów oraz dla obu form łącznie. Wyniki przedstawione są w Tabeli 3.

Tabela 3. Wyniki efektywności

\begin{tabular}{|l|c|c|c|c|c|c|}
\hline \multirow{2}{*}{ Skrót } & \multicolumn{2}{|c|}{ Łącznie } & \multicolumn{2}{c|}{ Stacjonarne } & \multicolumn{2}{c|}{ Niestacjonarne } \\
\cline { 2 - 7 } & Wynik & Rank & Wynik & Rank & Wynik & Rank \\
\hline AGH & $\mathbf{1 . 1 2}$ & 2 & $\mathbf{1 . 1 4}$ & 2 & $\mathbf{1 . 0 3}$ & 6 \\
\hline ATH & 0.78 & 8 & 0.79 & 10 & 0.80 & 9 \\
\hline PB & 0.63 & 15 & 0.67 & 14 & $\mathbf{1 . 0 4}$ & 5 \\
\hline PCz & $\mathbf{1 . 0 0}$ & 6 & $\mathbf{1 . 0 4}$ & 5 & 0.66 & 11 \\
\hline PG & 0.72 & 11 & 0.75 & 11 & 0.86 & 8 \\
\hline PK & 0.71 & 12 & 0.69 & 13 & $\mathbf{1 . 0 2}$ & 7 \\
\hline PKr & 0.81 & 7 & 0.88 & 7 & 0.46 & 14 \\
\hline PL & $\mathbf{1 . 0 8}$ & 4 & $\mathbf{1 . 1 2}$ & 3 & $\mathbf{1 . 0 9}$ & 3 \\
\hline PŁ & 0.51 & 17 & 0.54 & 17 & 0.43 & 16 \\
\hline PO & 0.64 & 13 & 0.63 & 15 & $\mathbf{1 . 0 8}$ & 4 \\
\hline PP & 0.76 & 10 & 0.85 & 8 & 0.43 & 15 \\
\hline PR & $\mathbf{1 . 1 2}$ & 3 & $\mathbf{1 . 0 7}$ & 4 & $\mathbf{1 . 3 2}$ & 1 \\
\hline PŚl & $\mathbf{1 . 0 1}$ & 5 & $\mathbf{1 . 0 2}$ & 6 & 0.79 & 10 \\
\hline PŚw & 0.77 & 9 & 0.83 & 9 & 0.63 & 13 \\
\hline PW & 0.64 & 14 & 0.69 & 12 & 0.28 & 18 \\
\hline PWr & 0.58 & 16 & 0.58 & 16 & 0.33 & 17 \\
\hline UTH & $\mathbf{1 . 3 7}$ & 1 & $\mathbf{1 . 4 2}$ & 1 & $\mathbf{1 . 2 3}$ & 2 \\
\hline ZUT & 0.44 & 18 & 0.48 & 18 & 0.63 & 12 \\
\hline Min & O.44 & & 0.48 & & 0.28 & \\
\hline Max & 1.37 & & 1.42 & & 1.32 & \\
\hline Średnia & O.82 & & O.84 & & o.78 & \\
\hline Odch. & O.25 & & 0.25 & & o.32 & \\
\hline & & & & & \\
\hline
\end{tabular}

Źródło: opracowanie własne. 
Dla lepszego zobrazowania zróżnicowania efektywności na studiach stacjonarnych i niestacjonarnych wyniki przedstawiono na Wykresie 1 (w porządku malejącym według wyniku efektywności na studiach stacjonarnych). Powszechna opinia, że studia niestacjonarne są studiami „gorszej jakości”, nie do końca się tu potwierdza. Z punktu widzenia celu tego artykułu i zastosowanej metody oceny nie można jednoznacznie stwierdzić, że na studiach niestacjonarnych obserwuje się niższą efektywność procesu dyplomowania. W czterech uczelniach, które są w pełni efektywne dla studiów stacjonarnych (UTH, AGH, PL i PR) obserwuje się również pełną efektywność na studiach niestacjonarnych. Dwie kolejne w pełni efektywne uczelnie dla studiów stacjonarnych (PCz i PŚl) w przypadku studiów niestacjonarnych mają zdecydowanie niższą efektywność, odpowiednio 0.66 i 0.79. Odwrotną sytuację można zaobserwować dla trzech uczelni, które są w pełni efektywne dla studiów niestacjonarnych (PB, PK i PO), a dla studiów stacjonarnych mają niską efektywność, odpowiednio 0.67, 0.69 i o.63. Potwierdza to celowość odrębnego analizowania tych dwóch form studiów.

Wykres 1. Wyniki efektywności dla studiów stacjonarnych i niestacjonarnych

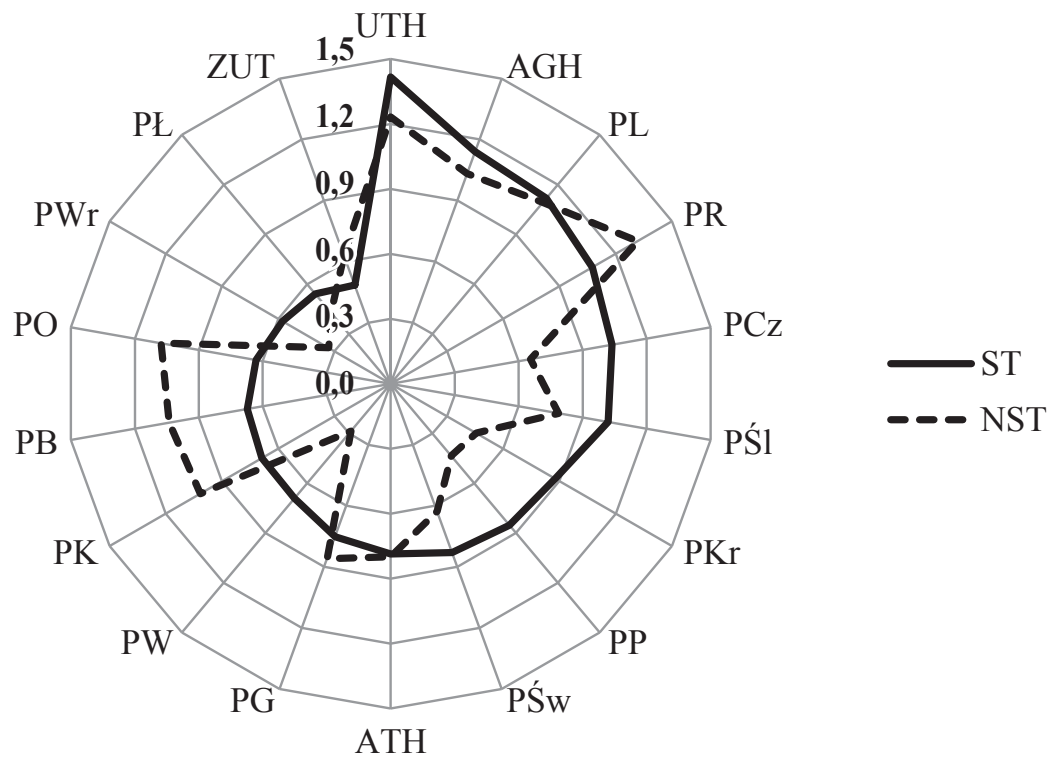

Źródło: opracowanie własne.

Na efektywność funkcjonowania uczelni wpływa bez wątpienia struktura kierunków studiów (subject mix) prowadzonych przez nie. Niektóre kierunki są bardziej pracochłonne i wymagające prowadzenia zajęc $\mathrm{w}$ mniejszych grupach, często z wykorzystaniem specjalistycznego wyposażenia laboratoryjnego (Sarrico i in. 2009). 
Dotyczy to większości kierunków technicznych. Powszechnie uważa się, że kierunki z grupy społecznych (np. zarządzanie, które prowadzone jest w większości uczelni technicznych) są mniej pracochłonne.

Wykres 2 przedstawia zależność efektywności uczelni od wskaźnika W6 określającego udział studentów studiujących na kierunkach technicznych. Bezwzględnym liderem jest UTH mający najwyższą efektywność i najniższy udział studentów na kierunkach technicznych (0.48). Podobnie niski udział jest w ATH i PK, jednakże poziom efektywności sytuuje się tam poniżej o.8. Tak więc jednoznacznie nie można stwierdzić też, że efektywność procesu dyplomowania jest zależna od struktury kierunków.

Wykres 2. Zależność efektywności od udziału studentów na kierunkach technicznych (studia stacjonarne i niestacjonarne łącznie)

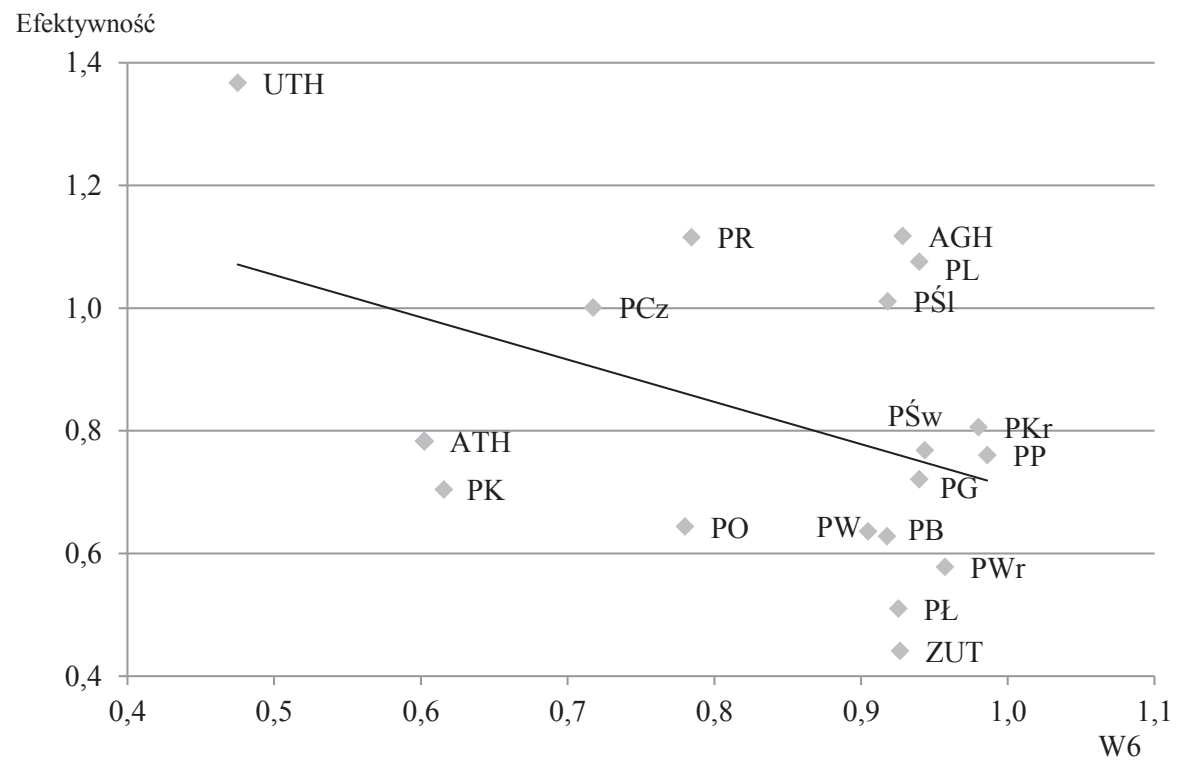

Źródło: opracowanie własne.

Na terminowe uzyskanie dyplomu studiów wpływają jednakże również inne czynniki, które nie zostały uwzględnione w proponowanym modelu, głównie z powodu braku odpowiednich danych. Jednym z takich czynników jest poziom przygotowania kandydatów do studiowania. Zwracają na to uwagę Sneyers i De Witte (2017) oraz Katharaki i Katharakis (2010). Ci ostatni podkreślają również, że na osiągnięcie sukcesu przez studentów znaczny wpływ ma liczba tych z nich, którzy muszą pracować w trakcie swoich studiów (również stacjonarnych) oraz zróżnicowane wymagania edukacyjne na poszczególnych uczelniach. Są to czynniki, które mogą tłumaczyć 
różnice w efektywności poszczególnych uczelni, jednakże trudno to zweryfikować, gdyż dane w tym zakresie są niedostępne.

DEA poza rankingami dostarcza wielu przydatnych wyników w postaci tzw. projekcji wartości zmiennych dla obiektów, które uznane zostały za nieefektywne. Ponieważ w artykule zastosowano model niezorientowany, optymalne rozwiązanie, jakie się uzyskuje, maksymalizuje pożądane rezultaty oraz minimalizuje niepożądane rezultaty oraz nakłady. Dla nieefektywnych uniwersytetów można więc uzyskać informacje, jakie powinny być docelowe wartości nakładów i rezultatów, aby te uczelnie osiągnęły pełną efektywność. W przypadku rezultatu ABS_2015, czyli liczby absolwentów, projekcja nie różni się w istotny sposób od wartości zarejestrowanych w roku 2015, zarówno na studiach stacjonarnych, jak i niestacjonarnych. Wyjątkiem dla studiów niestacjonarnych są PŁ oraz ZUT, gdzie liczba absolwentów powinna wzrosnąc odpowiednio o 9\% i 71\%. Znacznie bardziej istotne jest przeanalizowanie wymaganych zmian niepożądanego rezultatu, czyli liczby rezygnacji ze studiów między pierwszym i drugim rokiem (zmienna REZYGN). Jest to kluczowy czynnik obniżający efektywność. Wyniki przedstawione są na Wykresie 3.

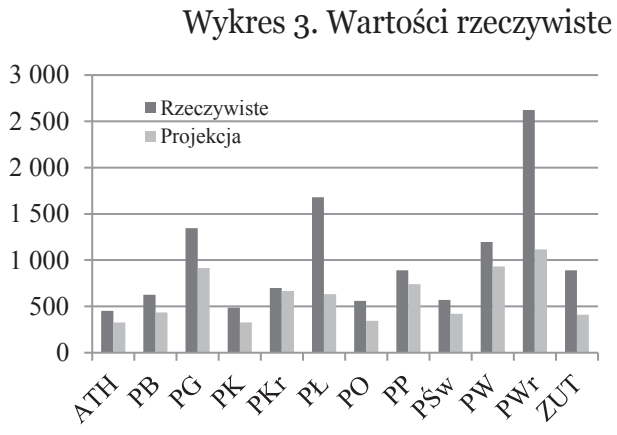

Studia stacjonarne

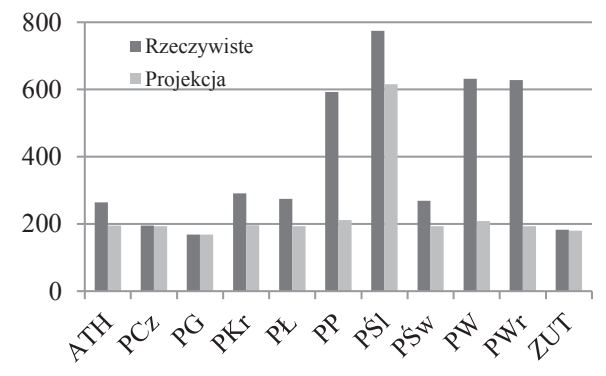

Studia niestacjonarne

Źródło: opracowanie własne.

Dla studiów stacjonarnych w trzech uczelniach (PG, PŁ i PWr) widać wyraźną konieczność zdecydowanego zminimalizowania niekorzystnego zjawiska rezygnacji ze studiów między pierwszym a drugim rokiem. Liczba osób rezygnujących powinna być odpowiednio zredukowana o 32\%, 62\% i 58\%. Przyczyn rezygnacji może być wiele, np. Sneyers i De Witte (2017) na podstawie swoich badań wskazali takie jak: brak satysfakcji studentów z realizowanego programu, brak odpowiedniego przygotowania pewnych grup studentów do kształcenia, brak wsparcia dla grup słabszych studentów. Zwracają też uwagę, że wysoki wskaźnik rezygnacji może wynikać z przyjętej na uczelniach polityki selekcyjnego charakteru pierwszego roku. W przypadku 
studiów niestacjonarnych są cztery uczelnie, w których liczba rezygnacji powinna być w istotny sposób zredukowana. Są to PP o 64\%, PŚl o 21\%, PW o 67\% i PWr o $33 \%$. W przypadku uczelni w dużych aglomeracjach prawdopodobną przyczyną tak dużego udziału osób rezygnujących ze studiów między pierwszym a drugim rokiem jest trudność pogodzenia pracy zawodowej ze studiami. Znacznie łatwiej znaleźć tam pracę, ale też wymagania stawiane przez pracodawców co do zaangażowania się w działalność zawodową są większe. Za wyjątkiem PO i PW wymienione wyżej uczelnie prowadzą bardzo liberalną politykę dotyczącą możliwości powtarzania pierwszego roku. Pierwszy rok powinien mieć charakter selekcyjny, jeżeli nie ma selekcji na wejściu na studia. Trudno bowiem uznać wynik z matury za wiarygodną podstawę oceny zdolności intelektualnych kandydata do podjęcia studiów.

Ponieważ w modelu niezorientowanym minimalizowane są również nakłady warto zwrócić uwagę na liczbę osób studiujących na pierwszym roku studiów. Przy dużych limitach przyjęć może bowiem dojść do sytuacji, że aby je wypełnić, zaniża się kryteria na wejściu, przyjmując słabych kandydatów. Na Wykresie 4 przedstawione są wartości rzeczywiste i pożądane zmiennej STUD_I_ROK_2011, czyli osób rozpoczynających studia, w tym przypadku w roku 2011.

Wykres 4. Wartości rzeczywiste i pożądane zmiennej STUD_I_ROK_2011

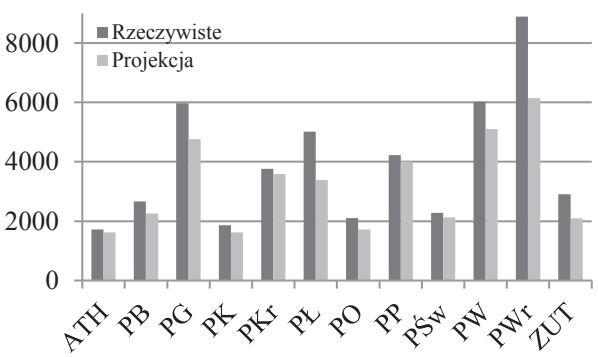

Studia stacjonarne

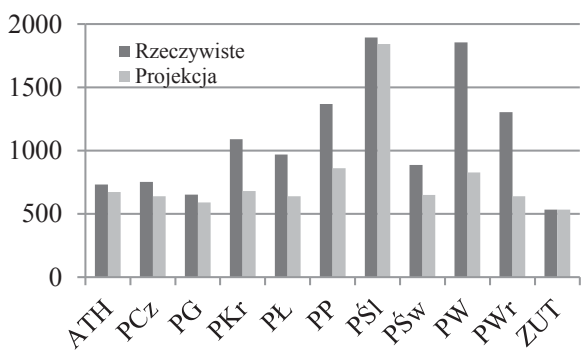

Studia niestacjonarne

Źródło: opracowanie własne.

Polityka rekrutacyjna ma również wpływ na efektywność procesu dyplomowania. Kilka uczelni dla osiągnięcia pełnej efektywności powinno zmniejszyć nabór studentów na pierwszy rok. W przypadku studiów stacjonarnych są to PG, PŁ, PWr i ZUT, które w istotny sposób powinny zmniejszyć liczbę studentów na pierwszym roku. Są to uczelnie, które stosują liberalną politykę powtarzania pierwszego roku. Np. PWr powinna zmniejszyć nabór na pierwszy rok o 2743 osoby, a około 870 osób w liczbie studentów pierwszego roku, to powtarzający; natomiast w przypadku PG powinno być na pierwszym roku mniej o 1210 osób, a powtarzających było 830. Tak więc niedopuszczanie do powtarzania pierwszego roku powinno w sposób zdecydowany 
poprawić efektywność. Zmniejszenie limitów przyjęć zostało od roku 2017/2018 wprowadzone i w przyszłości warto takie badania powtórzyć, aby sprawdzić, czy efektywność dyplomowania poprawiła się. W podobny sposób można przeanalizować i zinterpretować wyniki dla studiów niestacjonarnych.

\section{Podsumowanie}

Artykuł przedstawia ilościową analizę negatywnych aspektów funkcjonowania 18 wyższych uczelni technicznych w Polsce. Rozwój masowego kształcenia wyższego obserwowany na całym świecie ma wiele pozytywnych efektów, jednakże również wiele negatywnych, które coraz częściej stają się przedmiotem badań. Podstawowym problemem współczesnych systemów szkolnictwa wyższego jest relatywnie niska liczba absolwentów studiów pierwszego stopnia w stosunku do liczby osób rozpoczynających studia. $W$ przebadanych polskich uczelniach technicznych średnio $26 \%$ studentów przyjętych na pierwszy rok studiów pierwszego stopnia nie przechodzi na drugi rok (na podstawie danych z lat 2011-2012). Z tych, którzy rejestrują się na drugi rok, w nominalnym czasie kończy studia średnio 70\% (na podstawie danych z roku 2015). Z osób rozpoczynających studia w 2011 roku nie ukończyło ich w terminie 52\%, czyli w liczbach bezwzględnych jest to 42800 osób z 88800 rozpoczynających. Biorąc pod uwagę, że w polskich uczelniach technicznych średnio 80\% studentów uczestniczy w studiach stacjonarnych finansowanych ze środków publicznych, można stwierdzić, że około 40\% publicznych środków inwestowanych w stacjonarne studia pierwszego stopnia to raczej chybiona inwestycja, bo albo zwrotu nie będzie w ogóle, albo będzie po czasie dłuższym niż nominalny czas trwania studiów, gdyż wielu studentów „przedłuża” sobie moment złożenia i obrony pracy dyplomowej.

Warto zwrócić uwagę na trudności badania tego problemu wynikające z niedostępności odpowiednich danych. GUS od wielu lat publikuje masę danych, które bez wątpienia mają jakieś znaczenie, ale do tego typu analiz nie są użyteczne. Podstawowa trudność wynika z tego, że dane o liczbie studentów na poszczególnych latach studiów są podawane łącznie dla studiów pierwszego stopnia i jednolitych studiów magisterskich. Brakuje danych o liczbie nauczycieli akademickich, z uwzględnieniem stanowisk, w poszczególnych uczelniach. Co prawda MNiSW takie dane publikuje, ale nie są one powszechnie dostępne (a powinny być udostępnione na stronie internetowej ministerstwa). Nigdzie nie są publikowane dane o rezygnacji studentów między pierwszym i drugim rokiem studiów czy o terminowym ukończeniu studiów w nominalnym czasie ich trwania. Jedyna dostępna informacja to ile osób „ukończyto" studia bez obrony pracy dyplomowej. Oczywiście można te czynniki oszacować stosując różnego rodzaju proxy, tak jak miało to miejsce w tym artykule, ale takie 
oszacowania zawsze są obarczone pewnym błędem, co zostało podkreślone w sekcji doboru zmiennych. Jednakże lepiej mieć wyniki analiz ze świadomością tego, że obarczone są trudnym do oceny błędem, niż nie robić nic.

Wszyscy są przyzwyczajeni do tego, że rankingi odwzorowują powszechne przekonanie o światowej randze poszczególnych uczelni. Przedstawiony w tym artykule ranking należy interpretować dokładnie zgodnie z celem tego badania. Dwie uczelnie będące liderami w rankingach uwzględniających badania naukowe i prestiż, czyli PW i PWr, pod względem efektywności procesu dyplomowania znajdują się na samym dole tabeli ligowej, a UTH, który klasyfikowany jest przez MNiSW jako uczelnia techniczna, jest liderem, jednakże aż $52 \%$ studentów kształci na kierunkach nietechnicznych. To jest wynik złożoności problemu, który był już wcześniej sygnalizowany. Jest zbyt wiele czynników wpływających na rezygnację ze studiów między pierwszym i drugim rokiem czy przedłużania zakończenia studiów ponad nominalny czas ich trwania. Na podstawie przeanalizowanej literatury można wskazać kilka przyczyn. Podstawową wydaje się być przyjmowanie na studia kandydatów, którzy nie spełniają określonych wymagań tylko dlatego, żeby wypełnić limit. Tego nie da się udowodnić na podstawie dostępnych danych. Drugą przyczyną jest zróżnicowanie wymagań stawianych studentom, aby mogli zarejestrować się na kolejny semestr. Bardzo poważną przyczyną niskiej efektywności, co zostało wykazane w tym artykule, jest dopuszczanie przez niektóre uczelnie do powtarzania pierwszego roku. Kolejna przyczyna, bezpośrednio związana z poprzednią, to brak selekcji na wejściu na studia. Jeszcze raz trzeba podkreślić, że wynik z egzaminu maturalnego nie jest wystarczającą oceną zdolności kandydata do studiowania.

Problem jest poważny, jednakże nie jest nierozwiązywalny. Rozwiązaniem pokazującym przyczyny tych niekorzystnych zjawisk mogą być badania kohortowe. Wymagają one śledzenia poszczególnych studentów w trakcie ich cyklu edukacyjnego. Wyniki takich badań pozwoliłyby na zdiagnozowanie tego problemu i wskazanie jego przyczyn. Tego rodzaju wyniki pozwoliłyby na takie kształtowanie polityki wyższej edukacji, która zminimalizowałaby te negatywne zjawiska.

\section{Literatura}

Abbott, M. i Doucouliagos, C. (2003). The efficiency of Australian universities: A Data Envelopment Analysis. Economics of Education Review. 22(1): 89-97.

Agasisti, T. i Johnes, G. (2009). Beyond frontiers: Comparing the efficiency of higher education decision-making units across more than one country. Education Economics. 17(1): 59-79.

Agasisti, T. i Johnes, G. (2015). Efficiency, costs, rankings and heterogeneity: The case of US higher education. Studies in Higher Education. 40(1): 60-82. 
Agasisti, T. i Salerno, C. (2007). Assessing the cost efficiency of Italian universities. Education Economics. 15(4): 455-471.

Andersson, C., Antelius, J., Månsson, J. i Sund, K. (2017). Technical efficiency and productivity for higher education institutions in Sweden. Scandinavian Journal of Educational Research. 61(2): 205-223.

Archibald, R.B. i Feldman, D.H. (2008). Graduation rates and accountability: Regressions versus production frontiers. Research in Higher Education. 49(1): 80-100.

Barra, C. i Zotti, R. (2016). A directional distance approach applied to higher education: An analysis of teaching-related output efficiency. Annals of Public and Cooperative Economics. 87(2): 145-173.

Bonaccorsi, A. i Daraio, C. (2008). The differentiation of the strategic profile of higher education institutions. New positioning indicators based on microdata. Scientometrics. 74(1): 15-37.

Bonaccorsi, A., Daraio, C. i Simar, L. (2006). Advanced indicators of productivity of universities: An application of robust nonparametric methods to Italian data. Scientometrics. 66(2): 389-410.

Carneiro, P., Heckman, J.J. i Vytlacil, E. (2011). Estimating marginal returns to education. NBER Working Paper No. 16474. Cambridge: National Bureau of Economic Research.

Carrington, R., Coelli, T. i Prasada Rao, D.S. (2005). The performance of Australian universities: conceptual issues and preliminary results. Economic Papers. 24(2): 145-163.

Carrington, R., O’Donnell, C. i Prasada Rao, D.S. (2018). Australian university productivity growth and public funding revisited. Studies in Higher Education. 43(8): 1417-1438.

Cook, W.D., Tone, K. i Zhu, J. (2014). Data envelopment analysis: Prior to choosing a model. Omega-International Journal of Management Science. 44: 1-4.

Cooper, W.W., Seiford, L.M. i Tone, K. (2007). Data Envelopment Analysis: A comprehensive text with models, applications, references and DEA-Solver Software. New York: Springer.

Cooper, W.W., Seiford, L.M. i Zhu J. (2011). Handbook on data envelopment analysis. New York: Springer.

Daraio, C., Bonaccorsi, A. i Simar, L. (2015a). Efficiency and economies of scale and specialization in European universities: A directional distance approach. Journal of Informetrics. 9(3): $430-448$.

Daraio, C., Bonaccorsi, A. i Simar, L. (2015b). Rankings and university performance: A conditional multidimensional approach. European Journal of Operational Research. 244(3): 918-930.

De Witte, K. i Hudrlikova, L. (2013). What about excellence in teaching? A benevolent ranking of universities. Scientometrics. 96(1): 337-364.

EACEA-Eurydice (2015). The European Higher Education Area in 2015: Bologna Process Implementation Report. Luxembourg: Publications Office of the European Union.

Johnes, G. i Tone, K. (2017). The efficiency of higher education institutions in England revisited: comparing alternative measures. Tertiary Education and Management. 23(3): 191-205. 
Johnes, J. (1996). Performance assessment in higher education in Britain. European Journal of Operational Research. 89(1): 18-33.

Johnes, J. (2006). Data envelopment analysis and its application to the measurement of efficiency in higher education. Economics of Education Review. 25(3): 273-288.

Kallio, K.M., Kallio, T.J. i Grossi, G. (2017). Performance measurement in universities: ambiguities in the use of quality versus quantity in performance indicators. Public Money \& Management. 37(4): 293-300.

Katharaki, M., i Katharakis, G. (2010). A comparative assessment of Greek universities' efficiency using quantitative analysis. International Journal of Educational Research, 49(4-5): 115-128.

Lee, T., Zhang, Y. i Jeong, B.H. (2016). A multi-period output DEA model with consistent time lag effects. Computers \& Industrial Engineering. 93: 267-274.

Luca, S., Verdyck, M. i Coppens, M. (2014). An approach to estimate degree completion using drop-out rates. Studies in Educational Evaluation. 40: 43-49.

Lukman, R., Krajnc, D. i Glavic, P. (2010). University ranking using research, educational and environmental indicators. Journal of Cleaner Production. 18(7): 619-628.

Murias, P., de Miguel, J.C. i Rodriguez, D. (2008). A Composite indicator for university quality assessment: The case of Spanish Higher Education System. Social Indicators Research. 89(1): 129-146.

Olesen, O.B., Petersen, N.C. i Podinovski, V.V. (2015). Efficiency analysis with ratio measures. European Journal of Operational Research. 245(2): 446-462.

OECD (2004). OECD Handbook for internationally comparative education statistics: Concepts, standards, definitions and classifications. Paris: OECD Publishing.

OECD (2013). Education at a Glance 2013: OECD Indicators. Paris: OECD Publishing.

Safón, V. (2013). What do global university rankings really measure? The search for the $\mathrm{X}$ factor and the X entity. Scientometrics. 97(2): 223-244.

Sarrico, C., Teixeira, P., Rosa, M.J. i Cardoso, M.F. (2009). Subject mix and productivity in Portuguese universities. European Journal of Operational Research. 197(1): 287-295.

Sneyers, E. i De Witte, K. (2017). The interaction between dropout, graduation rates and quality ratings in universities. Journal of the Operational Research Society. 68(4): 416-430.

Thomas, L. i Hovdhaugen, E. (2014). Complexities and challenges of researching student completion and non-completion of HE programmes in Europe: A comparative analysis between England and Norway. European Journal of Education. 49(4): 457-470.

Tone, K. (2001). A slacks-based measure of efficiency in data envelopment analysis. European Journal of Operational Research. 130(3): 498-509.

Tran, Carolyn-Dung, T. T. i Villano, R.A. (2017). An empirical analysis of the performance of Vietnamese higher education institutions. Journal of Further and Higher Education. 41(4): 530-544.

Trow, M. (1973). Problems in the transition from elite to mass higher education. Berkeley: Carnegie Commission on Higher Education. 
Vossensteyn, H., Stensaker, B., Kottmann, A., Hovdhaugen, E., Jongbloed, B., Wollscheid, S., Kaiser, F. i Cremonini, L. (2015). Dropout and Completion in Higher Education in Europe. Main Report. Luxembourg: Publications Office of the European Union.

World Bank (2018). School enrollment, tertiary (\% gross). http://databank.worldbank.org/ data/reports.aspx?source=2\&series=SE.TER.ENRR\&country\# [02.06.2018].

Worthington, A.C. i Lee, B.L. (2008). Efficiency, technology and productivity change in Australian universities, 1998-2003. Economics of Education Review. 27(3): 285-298.

Zrelli, N. i Hamida, B. (2013). Efficiency and quality in higher education. A dynamic analysis.

Research in Applied Economics. 5(4): 116-130.

\title{
Assessment of the graduation process efficiency on the first degree studies in Polish public technical universities
}

\begin{abstract}
This paper presents an analysis and quantitative assessment of the functioning of 18 Polish technical universities taking into account two basic problems, first year dropout rate and graduation rate at a nominal time. To assess the efficiency of the graduation process, a simple indicator method and non-parametric Data Envelopment Analysis (DEA) method are used. The assessment is performed for undergraduate studies in a full-time and part-time form. A preliminary assessment of the phenomenon was made on the basis of simple indicators. In the DEA model, on the input side the number of commencing students in 2011, the number of academic staff and the total number of undergraduate students are taken into account. On the output side, the number of graduates from 2015 and the number of dropout students after the first year of studies are taken into account. This model allows to create a ranking and to calculate the target values of variables included in the analysis for inefficient universities. The interpretation of results includes previously defined indicators.
\end{abstract}

KEYWORDS: graduation rate, first year dropout rate, ratio analysis, data envelopment analysis, undesirable output

CYTOWANIE: Szuwarzyński, A. (2018). Ocena efektywności procesu dyplomowania na studiach pierwszego stopnia w polskich publicznych uczelniach technicznych. Nauka i Szkolnictwo Wyższe. 2(52): 85-111. DOI: 10.14746/nisw.2018.2.2

ANDRZEJ SZUWARZYŃSKI - Pracownik Katedry Zarządzania na Wydziale Zarządzania i Ekonomii Politechniki Gdańskiej. Zainteresowania badawcze związane z funkcjonowaniem szkolnictwa wyższego oraz kształcenia przez całe życie. Autor wielu publikacji poruszających tematykę oceny efektywności instytucji szkolnictwa wyższego, z wykorzystaniem metody Data Envelopment Analysis. e-mail: Andrzej.Szuwarzynski@zie.pg.gda.pl 